\title{
OPINION 972
}

PAPILIO SAPORTAE HÜBNER, 1828-1832 (INSECTA, LEPIDOPTERA): SUPPRESSED UNDER THE PLENARY POWERS

RULING.-(1) Under the plenary powers the specific name saportae Hübner, 1828-1832, as published in the binomen Papilio saportae, is hereby suppressed for the purposes of the Law of Priority but not for those of the Law of Homonymy.

(2) The specific name saportae Hübner, 1828-1832, as published in the binomen Papilio saportae (as suppressed under the plenary powers in (1) above) is hereby placed on the Official Index of Rejected and Invalid Specific Names in Zoology with the Name Number 969.

(3) The specific name melanops Boisduval, 1828, as published in the binomen Polyommatus melanops, is hereby placed on the Official List of Specific Names in Zoology with the Name Number 2467.

\section{HISTORY OF THE CASE (Z.N.(S.) 1875)}

The present case was submitted to the office of the Commission by Mr. N. D. Riley and Mr. L. G. Higgins in January 1969. The application was sent to the printer on 24 January 1969 and was published on 8 August 1969 in Bull. zool. Nomencl. 26 : 95-96. Public Notice of the possible use of the plenary powers in the present case was given in the same part of the Bulletin as well as to the other prescribed serial publications (Constitution Art. 12b; Bull. zool. Nomencl. 21 : 184) and to eight entomological serials. No comment was received.

\section{DECISION OF THE COMMISSION}

On 22 March 1971 the Members of the Commission were invited to vote under the Three-Month Rule on Voting Paper (71)5 either for or against the proposals set out in Bull. zool. Nomencl. 26:95-96. At the close of the prescribed voting period on 22 June 1971 the state of the voting was as follows:

Affirmative votes-sixteen (16), received in the following order: Mayr, Holthuis, Melville, Lemche, Vokes, Tortonese, Simpson, Alvarado, Eisenmann, Sabrosky, Jaczewski, Binder, Bonnet, Kraus, Brinck, Starobogatov

Negative votes-none $(0)$

Voting Papers not returned-three (3): Forest, Munroe, Ride

\section{ORIGINAL REFERENCES}

The following are the original references for names placed on the Official List and Index by the Ruling given in the present Opinion: melanops, Polyommatus, Boisduval, 1828, Europ. Lép. Index méth. : 13 saportae, Papilio, Hübner, 1828-1832, Samml. europ. Schmett. : pl. 188, figs. 922-925 


\section{CERTIFICATE}

I certify that the votes cast on Voting Paper (71) 5 were cast as set out above, that the proposal contained in that Voting Paper has been duly adopted under the plenary powers, and that the decision so taken, being the decision of the International Commission, is truly recorded in the present Opinion No. 972.

R. V. MELVILLE

Secretary

International Commission on Zoological Nomenclature London

15 September 1971 


\section{$2 \mathrm{BHL}$ Biodiversity Heritage Library}

International Commission on Zoological Nomenclature. 1971. "Opinion 972: Papilio saportae Hübner, 1828-1832 (Insecta, Lepidoptera): suppressed under the plenary powers." The Bulletin of zoological nomenclature 28, 147-148. https://doi.org/10.5962/bhl.part.6123.

View This Item Online: https://www.biodiversitylibrary.org/item/44470

DOI: https://doi.org/10.5962/bhl.part.6123

Permalink: https://www.biodiversitylibrary.org/partpdf/6123

\section{Holding Institution}

Natural History Museum Library, London

\section{Sponsored by}

Natural History Museum Library, London

\section{Copyright \& Reuse}

Copyright Status: In copyright. Digitized with the permission of the rights holder.

License: http://creativecommons.org/licenses/by-nc-sa/3.0/

Rights: https://biodiversitylibrary.org/permissions

This document was created from content at the Biodiversity Heritage Library, the world's largest open access digital library for biodiversity literature and archives. Visit BHL at https://www.biodiversitylibrary.org. 